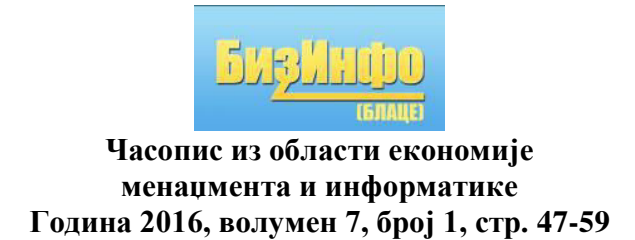

Година 2016, волумен 7, број 1, стр. 47-59

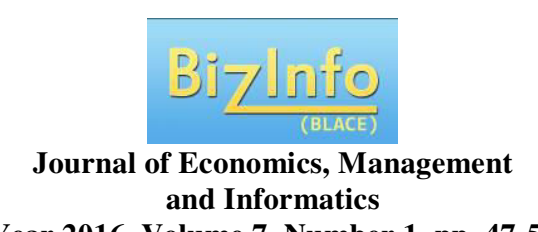

Year 2016, Volume 7, Number 1, pp. 47-59

Стручни рад/ Professional paper

УДК/UDC: 338.48-6:65(497.11)

DOI: $10.5937 /$ bizinfo1601047A

\title{
TRENDS IN BUSINESS TOURISM WITH A SPECIAL FOCUS ON THE CITY OF NIŠ AS A CONFERENCE DESTINATION
}

\section{ТРЕНДОВИ У ПОСЛОВНОМ ТУРИЗМУ СА ПОСЕБНИМ ФОКУСОМ НА ГРАД НИШ КАО КОНФЕРЕНЦИЈСКУ ДЕСТИНАЦИЈУ}

\author{
Mira Avramović ${ }^{1}$ \\ Higher Business School, Leskovac \\ Goran Perić ${ }^{2}$ \\ Business School of Applied Studies, Blace \\ Milan Komadina ${ }^{3}$ \\ Student of specialist studies, Higher Business School, Leskovac
}

\begin{abstract}
This paper explains the phenomenon of business tourism giving insight to its main concepts and types. The case study has special emphasis on the business tourist area of the City of Niš and deals with its potential for the development of this form of tourism. It has shown that the City of Niš as a tourist destination has appropriate infrastructure whose maximum use along with the assistance of well-planned destination management could further develop business tourism in the area. The Niš Fair, Čair Hall and a sufficient number of hotels that offer small and large conference venues represent a tourist destination management resource that should be recognized and valorized through the creation of many different business touristic offers in the form of a number of business conferences, exhibitions and trade fairs in
\end{abstract}

\footnotetext{
1avramovic.mira@vpsle.rs

22goran.peric@vpskp.edu.rs

${ }^{3}$ komadinamilan@yahoo.com
} 
the coming years. The MICE (business tourism) has an increasing trend in the Niš area and it would certainly exert a positive effect on the inflow of funds to the budget of the City of Niš.

Key words: trends, business tourism, Niš, conference destination

Сажетак: Овај рад објашњава феномен пословног туризма и пружа увид у његове главне концепте и врсте. Студија случаја даје посебни осврт на пословно туристичко подручје Града Ниша и обрађује потенцијал за развој овог вида туризма на датом подручју. Она је показала да Град Ниш као туристичка дестинаиија има одговарајућу инфраструктуру чијом би се максималном искоришћеношћу уз помоћ доброг планског дестинацијског менаимента могао даље развијати пословни туризам на овом подручју. Нишко сајмиште, Хала "Чаир", знатни број хотела који нуде мале и велике конференцијске сале представљају ресурс туристичког дестинацијског менаимента који би требало да буде препознат и валоризован кроз стварање низа различитих понуда пословног туризма, кроз велики број пословних скупова, изложби и сајмова у наредним годинама. МИЦЕ (пословни туризам) има растући тренд у нишкој области и могао би засигурно да врши знатни позитиван утииај на прилив финансијских средтава у бучет Града Ниша.

Кључне речи: трендови, пословни туризам, Ниш, конференцијска дестинащија

\section{INTRODUCTION}

People travel for many different purposes. A journey could be achieved for two main reasons; a job - business obligation and a pleasure which is free choice. In practice, tourists, of course, travel for pleasure. But it also doesn't mean that some of them would not use possible opportunity on vacation to establish some business contacts. On the other hand, business travelers, as well, find some time dealing with tourism activities between meetings, seminars and other business obligations. Travelling for the purpose of carrying out trade and engaging in commerce was one of the earliest types of tourist activity undertaken by enterprising members of ancient civilizations. Even at times in history when those undertaking any form of travel had to contend with the ever-present dangers of attack from bandits, pirates and highwaymen, as well as the severe discomfort of slowly progressing along poorly constructed roads or across perilous seas, the business motive was strong enough to drive intrepid merchants and other entrepreneurs to leave their native lands in search of distant markets in which to buy or sell goods and products not found locally. Today, business tourism - principally travel for commercial, professional and work related purposes - represents the major non-leisure form of tourism and business tourists are widely 
recognized as the highest-spending categories of business tourism and the trends affecting this industry.

\section{CONCEPT AND TYPES OF BUSINESS TOURISM}

One of the most important types of organizational business is group business. It is important for marketing managers to understand the differences between a group market and a consumer market. The group business market is often more sophisticated and requires more technical information than the consumer market. Many group markets book more than a year in advance. During this time, cognitive dissonance can develop; thus, marketers must keep in contact with the buyer to assure them that they made the right decision in choosing the seller's hotel. The four main categories of group business are conventions, association meetings, corporate meetings, and SMERF (social, military, educational, religious, and fraternal organizations) groups. Conventions attract large numbers, but meetings occur much more frequently than conventions. There are about ninety-five meetings held for each convention. Fifteen hundred people attend the average convention, 78 people attend the average corporate meeting, and 165 people attend the average association meeting (Kotler, Bowen and Makens, 2010). When choosing a hotel, an important consideration for a meeting planner is whether the hotel can house the participants. Most hotels have the potential of attracting hundreds of small meetings, whereas larger hotels can attract conventions. Group business is a very important segment for most hotels. Successful hotels know which groups to attract, how to use group business to fill need dates, and how to sell groups on the hotel's benefits rather than just price. The Convention Industry Council (CIC) is made up of thirty-four member organizations that represent both buyers and suppliers to the meetings industry. They recently developed the Accepted Practices Exchange (APEX), which brings a set of standards and best practices to all parties involved in the creation and implementation of a meeting. APEX's event specifications provide a template of a checklist for planning an event, and its glossary brings a common meaning to terms used in the meetings industry. APEX is a great tool for those involved in selling or planning meetings. Modern-day business tourism takes four principal forms: travel for the purpose of attending conferences and other types of meetings, incentive travel, travel to attend an exhibition or trade fair and individual business travel. In the vast majority of cases, each category of business tourism is in some way connected to the traveler's professional life or their role in the buying and selling process that underpins much of modern commercial life. 


\section{TRENDS IN BUSINESS TOURISM}

The rest of this chapter looks at some of the most important trends that will present opportunities and challenges to the global business tourism industry in the years ahead. Many of those trends are already emerging and others may be anticipated because of changes in the wider market environment. The market for business tourism services and facilities is an extremely dynamic one that is highly sensitive to changes in the political, economic and social environment. This sector is also affected by the accelerating rate of innovation in information and communications technology. On one hand it offers significant opportunities for the development of more attractive business tourism products, but, on the other, may also create certain threats to the long-term prosperity of this sector.

\subsection{ECONOMIC TRENDS}

The rise of new business tourism destinations in many developing economies of the world is a major - and ongoing - phenomenon in this sector. People travel for a variety of reasons, such as leisure, visiting relatives, medical treatments and of course business reasons. Service sector holds the most important position in the structure of the world economy, participating in the creation of GDP of a large number of developed and less developed countries with over 60 percent (Petrovic and Mirkovic, 2010). As recently as 60 years ago, North American cities and European capitals had a practical monopoly over the hosting of inter-national association meetings, for example. They were virtually the only places equipped with the infrastructure required to host these large-scale events. The decades since then, however, have seen a burgeoning of destinations entering all sectors of the business tourism market: Australasia, South East Asia, South America and, more recently, Central and Eastern European countries and cities in the Middle East have entered the market as vibrant new destinations for the hosting of meetings, trade shows and incentive trips. At the same time, developing economies create additional demand for business tourism events as their new businesses add to the need for corporate events, and members of the expanding professional classes increasingly have the means to travel to conferences and exhibitions in other countries. This phenomenon is particularly seen in China and India, two of the world's fastest-growing economies, and countries widely believed to be major sources of international business tourism consumption in the years to come. These two countries represent the two economies that are set to generate the greatest expansion in outbound business travel for the short and medium term. Citizens of these countries are already travelling to other destinations in their own regions, on business, but they will extend their scope to Europe and other long-haul destinations in rapidly increasing numbers in the years ahead. In China, growing levels of 
personal disposable income, Chinese companies' investment overseas and a fast-increasing number of international air connections with cities in major destinations are factors that will ensure the rapid growth of Chinese outbound corporate meetings and incentive trips and Chinese delegates at international association meetings and exhibitions in the near future.

\subsection{GROWING CORPORATE COST-CONSCIOUSNESS}

As competition between business tourism venues and destinations intensifies, buyers have become aware that they are purchasing services in a buyer's market. Much of the corporate market in particular has lost no time in reaping the benefits of this situation and meeting planners have quickly learned how to negotiate to their best advantage. With no sign of imminent change in the relationship between supply and demand, corporate buyers are set to become even more cost-conscious in the years ahead. Almost every survey of demand for business tourism events suggests that corporate buyers expect the number of events they organize to increase in the immediate and short term future, but there is no corresponding indication that their budgets are going to increase at a proportional rate. On the contrary, most surveys reveal a general reduction of per-delegate expenses as the central issue for many companies becomes that of ensuring better overall value and a higher return on their investment. Therefore, all business tourism destinations, and the venues within them, must constantly look for ways to manage their tariffs and demonstrate the cost effectiveness of these. Quality, but at an attractive price, will be a dominant requirement for the foreseeable future, as the majority of businesses now recognize the strengths of their considerable purchasing power.

\subsection{TECHNOLOGY TRENDS}

Information and communications technology (ICT) has already transformed many aspects of the business tourism sector and there is no doubt that further advances in ICT will continue to have a profound impact on how such events are planned, promoted and experienced in years to come. Young people now entering employment in this sector will never understand the extent to which the Internet alone has revolutionized the planning, marketing and execution of events such as conferences and exhibitions. It is rare indeed, nowadays, to find a major conference or exhibition without its own website, where potential participants can read, in advance, full details of the event, register to attend and plan their schedule for the event itself. Developments such as PowerPoint and hand-held devices that allow the audience to respond in real time to conference presentations have enhanced delegates' experience, while radio frequency identification (RFID) promises to make the tracking and identification of exhibition visitors more efficient. The rate of Wi-Fi 
deployment in conference and exhibition venues and in large hotels is expanding fast and is increasingly expected by people travelling on business.

\subsection{SOCIAL TRENDS}

Changes in the profile of the global working population have, in turn, had a very significant effect on the profile of participants in business tourism events. The most prominent of these is the ongoing increase in the proportion of women in professional employment. Women's share of professional jobs continued to increase in the first few years of the twenty first century in the vast majority of countries, and this trend shows every sign of continuing. Women are already well represented in a number of professions, such as healthcare and finance that are expanding rapidly in most countries. Women are also making inroads into traditionally male-dominated professions. For example, in some countries, the women's share of the ICT sector is already significant. This continuing trend means that there are more women travelling on business, for all work related purposes, including participation in conferences and exhibitions. The growing presence of female delegates at such events has had a number of impacts on business tourism services, from how conference and exhibition venues are designed (more toilet facilities for women), to the food served during breaks (lighter and generally healthier). Another indication of the feminization of the market is the increase in popularity of spas as incentive travel products - and not only for women. Partly through the influence of female participants, the spa has become an amenity that a growing number of delegates expect in hotels and resorts (Todorovic, 2013). The European and North American working population is ageing significantly and will continue to do so for the foreseeable future, adding to the proportion of those in employment who are in the older age categories. Increasingly, people in their sixties and seventies are remaining in employment, either through choice (they find fulfillment through their work) or through necessity (they cannot afford to retire). With a significant proportion of workers in the older age groups working in managerial and professional positions, it is highly likely that they will continue to travel on business and to business events, for a number of reasons.

Because they can! As members of the baby boom generation start to enter their sixties, it is clear that they are considerably healthier, fitter and more socially involved than those of the previous generation were at that age. Travelling to business events and fully taking part in them presents them with none of the physical challenges that their parents would have faced in their sixties.

Older workers understand that networking is particularly important to them as the type of upper level management positions they are often seeking are not 
likely to be advertised. Attending conferences of their professional associations provides them with a valuable opportunity to network.

There is a positive relationship between older workers staying in the workforce and their need for ongoing training opportunities. Particularly with so many older workers continuing to work in the fast-evolving 'knowledge industries', constant in-service training events are vital to them for keeping their skills up to date. This means that they will be increasingly present at corporate meetings that have a training objective.

A growing number of retired people are choosing to continue being members of their professional associations - in many cases, for the mental stimulation that profession-based meetings provide, as well as for the opportunity to maintain contact with colleagues.

\section{CASE STUDY - NIŠ AS A CONFERENCE DESTINATION}

The city of Niš is the third Serbian city by size. It is situated by the river Nišava. Niš is a cultural, economic, commercial and university seat of southeast Serbia. A city located 192 meters above sea level and spanning the surface area of 600 square kilometers. Its population is over 250.000 inhabitants. It is a university center with 13 faculties and one of the oldest European cities, as testified by numerous prehistoric finds on the territory of the city. A city long known as "the east/west gateway" since it is situated at a crossroads connecting Europe with the Middle East. The city is connected to the world with airlines departing from "Constantine the Great" international airport. Niš is well connected to the Serbian and European railroad network, too. Its train station is located at the city exit leading south to Leskovac and is a 20 minute walk away from the city core. All regional and international buses come to Niš and go from the main bus station near the green market and fortress of Niš, 10 minutes walking from the city center. When it comes to traveling by car, it is very well connected by road since it is situated at a European crossroads. The European highway E-75 coming from Hungary branches in two directions near Niš: towards the south, Macedonia and Greece (E-80) and towards the east, along Nišava valley, toward Bulgaria, Turkey and further on to the Middle East. Extending from Niš there are also roads to the northwest (toward Zaječar, Kladovo and Timisoara in Romania) and the southwest (toward the Adriatic Sea). It is surrounded by magnificent mountain ranges of Suva Mount, Svrljig Mount and Seličevica Mount. As well it is the birthplace of the famous Roman emperor Constantine the Great. The city of Niš annually hosts over 70.000 visitors (Živanovic, et. al. 2014) from across the country and around the globe. 


\subsection{CONFERENCE (CONGRESS) FACILITIES OF NIŠ}

In consideration of the role and importance of business tourism (MICE product), as a tourist destination Niš started from the vision of positioning Niš' business tourist market. Thanks to its geographical position and existing traffic infrastructure, the city has opportunities to develop tourist offer and successful positioning in the market of business tourism.

Table 1. Conference capacity of Niš

\begin{tabular}{|c|c|c|c|}
\hline Hotel & $\begin{array}{c}\text { Congress } \\
\text { (conference) halls } \\
\text { up to } 500 \text { seats } \\
\end{array}$ & $\begin{array}{c}\text { Congress } \\
\text { (conference) halls } \\
\text { up to } 200 \text { seats } \\
\end{array}$ & $\begin{array}{c}\text { Congress } \\
\text { (conference) halls } \\
\text { up to } 100 \text { seats } \\
\end{array}$ \\
\hline Hotel "Vidikovac" & $\begin{array}{l}\text { Conference hall with } \\
500 \text { seats } \\
\text { congress hall of } 250 \\
\text { seats }\end{array}$ & & \\
\hline Hotel "Grand" & $\begin{array}{c}\text { conference hall of } \\
330 \text { seats }\end{array}$ & $\begin{array}{c}\text { congress hall of } 130 \\
\text { seats }\end{array}$ & \\
\hline $\begin{array}{c}\text { Institute of Niška } \\
\text { Banja, hotel "Radon" }\end{array}$ & $\begin{array}{c}\text { congress hall of } \\
260 \text { places } \\
\end{array}$ & & $\begin{array}{c}\text { congress hall of } 60 \\
\text { places }\end{array}$ \\
\hline $\begin{array}{l}\text { Hotel "Tami } \\
\text { Residence" }\end{array}$ & & $\begin{array}{c}\text { conference hall of } \\
180 \text { seats }\end{array}$ & $\begin{array}{l}\text { conference hall of } 60 \\
\text { seats } \\
\text { congress hall with } 40 \\
\text { seats, } \\
\text { congress hall with } 30 \\
\text { seats }\end{array}$ \\
\hline Hotel "Aleksandar" & & & $\begin{array}{c}\text { conference hall of } \\
100 \text { seats }\end{array}$ \\
\hline
\end{tabular}

Source: Tourism organization of Niš, Serbia, 2016

\subsubsection{HOTEL "VIDIKOVAC"}

Hotel Vidikovac was established in 2002 (www.vidikovac-nis.com). The most exclusive and influential social events have left their mark on the life of the hotel, which is still present despite the passage of time. It is located on a place giving the most beautiful view from the lookout of the city of Niš. Hotel creates an intimate atmosphere, relying on a unique combination of old spirit and modern design. In its composition hotel features 76 rooms and 9 suites. Hotel's philosophy states that every meeting implies different customer needs. From small corporate meetings to large-scale congresses, customers can enjoy the flexibility of creating the schedule according to their needs. All conference rooms are equipped with audio and video technology and technical support. The staff of the Hotel Vidikovac consists of a team of professionals capable to realize and achieve your ideas. Many years of experience in organizing business meetings, perfect ambience and superbly equipped rooms are a good foundation for achieving your goals. The congress 
center has 2 air-conditioned rooms and covers an area of 500 square meters for up to 300 participants. There is a possibility of organizing seminars in four separate rooms of 100 attendees. All halls are equipped with adequate multimedia equipment. From the wide range for making presentations to the cloud data storage systems secured via the website of the hotel.

\subsubsection{HOTEL "TAMI RESIDENCE"}

Opened in September 2009, the Tami Residence Hotel is situated at the very heart of the convention and sports complex of the Tami - Trade d.o.o. Company, located at one of the most beautiful viewpoints of the City of Niš, only two kilometers from the downtown, well connected with the commercial centre of the city (www.tamiresidence.com). The hotel is positioned in a quiet environment, reflecting the beauty of surroundings and specificities of the ancient imperial Niš. There are also a free parking and garage, enabling organizing of various events and stay of guests in the Hotel. In the modern ambience of the Hotel that exudes European elegance and Southern hospitality, it is managed to mix business and pleasure in order to provide a sense of home atmosphere and a pleasant stay for our guests. This Hotel is characterized by a special devotion to and care for the guests and first-class service in each domain. Hotel capacity is 60 standard and deluxe rooms, including 4 suites and the Tami Residence annex with 10 deluxe rooms. Hotel offers two elegant conference halls and three meeting rooms, perfectly adjusted to the needs of modern business people. All the premises are air conditioned with natural and artificial light of high quality, equipped with complete audio/video support, stereo surround system, wireless internet, LCD TV devices, DVD players, lap tops and flipcharts. The Convention Center consists of a separate room technically equipped for simultaneous interpretation, with professional and technical support of our staff. The expert team of the Tami Residence Hotel is available for professional design and organizing of various types of business events like conferences, seminars, workshops, meetings, social and cultural events. All the premises offer the possibility of mutual communication in the form of video-conference. Hotel also offers a modern convention centre - several multifunctional conference halls with between 250 and 180 seats and meeting rooms with between 100 and 50 seats. The halls are equipped according to high standards and trends, offering a pleasant ambiance, technical support of professional staff and service tailored to fit the requirements of event organizers. Hotel affords to its guests moments of relaxation after daily duties in the newly opened SPA \& Wellness Centre TAMI which offers various types of massage, fitness program, sauna, tepidarium and Jacuzzi. 


\subsubsection{HOTEL "GRAND"}

Hotel Grand is located in the center of Niš across the main city square. It is a high quality, 4-star hotel. It was built to the highest technological and ecological standards (www.grandhotelnis.com). The hotel has a state of the art BMS (Building Management System), which saves energy and regulates central air-conditioning and ventilation. In addition to natural ventilation in public areas and rooms, fresh air is introduced through the air-conditioning system. Hotel Grand is the first big modern hotel in Niš. It has 120 rooms and suites, two large conference and banquet halls, elegant restaurant. Due to its superb location, high quality and affordable prices it is the natural choice for those who expect only the best hotel in the city and are not willing to compromise on quality. Hotel Grand offers excellent conditions for holding successful conferences, seminars, corporate celebrations, meetings and workshops. Excellent location, luxurious ambience, modern and wellequipped conference rooms have made hotel Grand the leading venue in town for top-level meetings and events. Hotel has two large, modern conference halls and one meeting room. They are equipped with complete audio/video support. Grand hall is located on the reception level. Exceptional ambiance and natural lighting makes Grand hall ideal for organizing conferences, seminars, banquets and all other major events. It is equipped with flip chart, projector, screen, sound system air condition. Wi-Fi is all over the hall. Metropolitan hall - Located on the first floor. The modern décor, natural lighting, simultaneous translation system and balcony for coffee break makes Metropolitan hall ideal for all kinds of business meetings and events. Boardroom - VIP meeting room with a fixed setting, for a maximum of twelve people. It is ideal place for business meetings, equipped with projector, screen, flip chart, lap top, LCD monitor and Wi-Fi access. Many well-known companies regularly held successful conferences and seminars in hotel Grand such as Roche, Actavis, Beiersdorf, Generali insurance, Vaillant, Telenor, Unicredit bank, Raiffeisen bank, Avon, Herbalife, Philip Morris, Johnson Electric and many others.

\subsubsection{HOTEL "RADON" - INSTITUTE OF NIŠKA BANjA}

The Institute "Niška Banja" is a health, scientific-teaching and investigating institution which deals with treatment and rehabilitation of patients suffering from cardiovascular and rheumatic diseases (www.radonnb.co.rs). The Institute is equipped with contemporary medical apparatuses for diagnostics and treatment in the field of non-invasive cardiology diagnostics, rheumatology, and orthopedic surgery, as well. Total lodging capacity of the Institute is 560 beds, located in three stationeries: "Radon", "Zelengora" and "Terme". Each of the stationary is unite for itself and it consists, beside lodgings, of a complete therapy block (hydro, kinetic, electro and mud), as 
well as numerous, various gyms for both organized group and individual recreation and fun. Beside health-recreate tourism the Institute offers all guidelines for both organizing and maintenance of sport tourism (tennis courts, both open and covered basket-ball and hand-ball court as well as a yard for small soccer, start terrains for paragliding), as well as for Congress tourism (amphitheater with contemporary technique equipment, with 300 seats, plenum auditory with 60 seats), restaurants and saloons for various occasions (meal serving and parties) with well-known national dishes. There are many medical symposium held for medical experts in facilities of the "Radon" Institute each year. Faculty of Medicine, University of Niš held different conferences of many medical fields such as Rheumatology, Osteoporosis, Cardiovascular, etc.

\subsubsection{HOTEL "ALEKSANDAR"}

Hotel Aleksandar is a luxurious hotel of the highest class in the south part of the City of Niš, located on a hill which offers a panoramic view of the city (hotel-aleksandar.com). Four minutes from the city center, this contemporary building is a perfect choice whether your stay is for business or pleasure, tourist or transient. The hotel prides itself on a wide range of services, hospitable and professional staff, luxury amenities, secure and guarded parking lot and a welcoming atmosphere, where one can enjoy a choice of local and international cuisine prepared by top chefs. Our mission is your satisfaction. Completely separate space covering 420 square meters, designed for organizing large gatherings such as conferences, symposiums, lectures, promotions, as well as cocktails and receptions. The Conference hall can accommodate 150 people using cinema style seating, and 80 people using amphitheatre style seating. A separate room for lecturers and complete technical logistics necessary for holding large gatherings are provided. All this make the Congress center of hotel Aleksandar the most exclusive venue of this kind suitable for prestigious events.

\subsubsection{HALL "ČAIR"}

Hall "Čair" covers an area of 11.000 square meters and 700 square meters of business space (www.sccair.rs). The building was founded in 1972 and put into operation in 1974 and in 2011 was completely reconstructed. It has a universal character so that in addition to extreme sports purposes can be used for fairs, exhibitions, concerts, screenings of films, theatrical performances and various cultural - entertaining programs. Capacity for sports events is 4.000 seats, and for other types of programs 6.500 seats. Next to the building is a hotel with 50 beds and a restaurant with 200 seats, a small hall for training which hosts some minor matches, Press Center, which serves as a 
space for different kinds of presentations, press conferences, promotions and hospitality.

\subsubsection{NIŠ FAIR}

Niš Fair is located in the Niš part of city named "Duvanište". Its area is 2.306 square meters and has 98 exhibition booths and 4 premises. In front of the fairgrounds, there is a large parking (www.trznicanis.rs). Every year Niš fairground maintains a multitude of exhibitions and trade fairs for which many business people from Southeast Serbia within groups and as individuals visit Niš.

\section{CONCLUSION}

This paper has reviewed the elements and characteristics of the business tourism sector, as well as some of the key trends and challenges that the sector is already dealing with and will continue to face in the future. There can be no doubt that the market environment for business tourism will continue to evolve and mutate in ways that are perhaps impossible to predict at the present time. It is in this very unpredictability, however, that the challenge and excitement of operating in this sector of the travel and tourism industry lies. In the complex, volatile flux of market trends and forces, one element that will remain reassuringly constant is human nature itself. Men and women will continue to attend business tourism events, not only for the opportunity to obtain personal and professional development for themselves and business growth for their organizations but also for the simple pleasure of meeting those with whom they share a common interest or goal. Buyers and participants will be drawn to attractive destinations and venues that deliver efficiently run and memorable events, using state-of-the-art technology, as well as distinctive cultural experiences in a healthy and unique environment. Niš is becoming increasingly popular as a conference destination and it disposes sufficient accommodation facilities for the development of business tourism events.

\section{REFERENCE}

1. Abel, A. B., Bernanke, B. S., Croushore, D., 2008. Macroeconomics. Boston: Pearson International Edition.

2. Holloway, J. C., Humphreys, C. Davidson, R. 2009. Eighth editoin. The Business of Tourism, Edinburgh: Pearson Education Limited.

3. Hill, C. W. L., McShane, S. L., 2008. Principles of Management. Maidenhead: McGRAW-HILL Book Company Europe. 
4. Kotler, P., Bowen, J. T., Makens, J. C., 2010. Marketing for Hospitality and Tourism. New Jersey: Pearson Education.

5. Morden, T., 1993. Business Strategy and Planning. Maidenhead: McGRAW-HILL Book Company Europe.

6. Mangan, J., Lalwani, C., Butcher, T., 2008. Global Logistics and Supply Chain Management. New Jersey: John Wiley \& Sons.

7. Todorovic, Z., 2013. Handbook for quality services and products in balneology, spa and wellness tourism "BSWT". Niš: Hajdi.

8. Petrovic, P., Mirkovic, A., 2010. The importance of tourism for regional development and cross-border cooperation. The Business of Tourism, No. 6/2010, pp. 7-15

9. Rabotić, B., 2012. Selektivni oblici turizma, [pdf] Available at: $<$ http://www.visokaturisticka.edu.rs/skripte/selektivni_novo/preda vanje8.pdf $>$ [Accessed April 25, 2016]

10. Smith, R. A., 2012. Corporate social responsibility: economic influence of tourism and sustainable development. The Business of Tourism, No. 9/2012, pp. 5-14

11. Živanović, N., Đordjević, M., Todorović, J., Marjanović, I., Zdravković, A., Petrović, M., 2014. City of Niš. Niš: Tourism organization of Niš.

12. Turisticka organizacija Niš, 2015. Hoteli. [online] Available at: $<$ http://www.visitnis.com/hoteli.html> [Accessed April 25, 2016]

13. Hotel "Vidikovac", 2015. [online] Available at: $<$ http://www.vidikovac-nis.com/>[Accessed April 25, 2016]

14. Hotel "Grand", 2015. [online] Available at: $<$ http://www.grandhotelnis.com/> [Accessed April 25, 2015]

15. Institute for treatment and rehabilitation "Niska Banja" , 2016. [online] Available at: <http://www.radonnb.co.rs/ci/> [Accessed April 25, 2016]

16. Hotel "Tami Residence", 2013. [online] Available at: $<$ http://www.tamiresidence.com/> [Accessed April 25, 2016]

17. Hotel "Aleksandar" [online] Available at: <http://hotelaleksandar.com/> [Accessed April 25, 2016]

18. Hall "Cair", 2015. [online] Available at: <http://sccair.rs/o-hali/> [Accessed April 25, 2016]

19. Niš Fair, 2005. [online] Available at: $<$ http://www.trznicanis.rs/pijace-duvaniste.htm> [Accessed April $25,2016]$

Рад је примљен: 27.04.2016.

Прихваћен за објављивање: 11.05.2016.

Received: 27 April 2016

Accepted: 11 May 2016 